\title{
In vitro Studies of the Effectiveness of Five Plants Extracts compared to Carbofuran in Controlling the Root Knot Nematode Meloidogyne incognita
}

\author{
NDANA, R.W. and *OYEDUNMADE, E.E.A. \\ Department of Biology, University of Abuja, \\ P.M.B. 117, ABUJA \\ beckyndana@yahoo.com \\ *Department of Crop Protection, \\ University of Ilorin \\ Ilorin.
}

\begin{abstract}
The crude aqueous extracts of five plants, Cleome viscosa L. Hyptis suaveolens Poit, Crotalaria retusa L., Jatropha curcas L., and Jatropha gossypifolia l., and a synthetic nematicide Carbofuran were studied in-vitro for their efficacy in controlling the rootknot nematode, Meloidogyne incognita (Kofoid and White) Chitwood. The experimental design was a randomized complete block design. The extracts were applied at 0, 5, 10, 15 and 20\% while carbofuran was applied at 0, 100, 1000, 10,000 and 100,000 ppm. Fifty (50) freshly extracted eggs as well as fifty (50() freshly hatched juveniles were used. Observations were made after one (1), six (6), twenty four (24), forty-eight (48) seventytwo (72) hours for juvenile mortality and one (1), three (3), five (5) and ten (10) days for egg hatch. All the treatments were replicated five times. It was observed that no eggs hatched in the higher concentrations $(20 \%$ and $100 \mathrm{mg} / \mathrm{ml})$ respectively of the plant extracts and carbofuran. It was also observed that by 24 hours all the juveniles that were exposed to $1 \mathrm{mg} / \mathrm{ml}, 10 \mathrm{mg} / \mathrm{ml}$ and $100 \mathrm{mg} / \mathrm{ml}$ carbofuran concentrations as well as more than 50\% (59 98\%) of all the juveniles in the 15 and 20 percent concentrations of all the plant extracts had died. All the treatments applied were superior in their effects in inhibiting egg hatch and causing juvenile death as compared with the control (distilled water only). Efficacy of treatments improved with increase in their concentrations and time of exposure of the nematode to treatment.
\end{abstract}

Key words: Test plants, aqueous extracts, toxicities, root-knot nematode egg, juveniles.

\section{INTRODUCTION}

The root-knot nematode, Meloidogyne incognita (Kofoid and White) Chitwood (1949) starts life as eggs. These develop rapidly into the first stage juvenile $\left(J_{1}\right)$ nematodes. This first stage juvenile remains inside the egg where it molts into a second stage juvenile $\left(\mathrm{J}_{2}\right)$ nematode, which moves out of the egg shell. This $\mathrm{J}_{2}$ can initiate infections on contact with the succulent tissue of the root tip of a susceptible host plant (Nwauzor and Fawole, 1992). In nematode control, strategies therefore can be aimed at inhibition of egg hatch or elimination of the second stage juvenile, which will mean 
effective control of root- knot nematode infection in susceptible plants.

In recent years, so many plants and their parts are being screened and identified with promises of nematicidal and nematostatic effects. This is necessary because of the negative side effects of synthetic nematicides on the environment and agricultural produce as well as the high cost of such nematicides. Several researchers including Ajayi et al. (1993), Oyedunmade (2004) and Abolusoro (2005) have reported on the inhibitory effects of some plant extracts on nematode egg hatch and juvenile survival. However, the list of plant materials with ovicidal and larvicidal potentials seems to be inexhaustible (Amadioha, 2003).

The aim of this research was to investigate the laboratory toxicities of crude aqueous extracts of Jatropha curcas L., J. gossypifolia, Cleome viscosa L., Crotalaria retusa $\mathrm{L}$. and hyptis suaveolens Poit to the eggs and juveniles of the root knot nematode, Meloidogyne incognita race 2. It was also intended to compare the toxicities of the test plants with that of a proven synthetic nematicide, carbofuran (furadan).

\section{Processing plant materials}

\section{MATERIALS AND METHODS}

The crude water extracts of the leaves of five plants were prepared separately in the laboratory using the method of Saxena and Mathela (1996). One (1) $\mathrm{kg}$ of each of the air-dried plant materials was soaked in 1 litre of water for 24 hours after which the filtrate was concentrated on a water bath to remove excess solvent. The slurry obtained was taken to be the stock solution $(100 \%)$. Serial dilutions were made from the $100 \%$ concentrated plant extracts to obtain the following concentrations;

$0 \%$ extract or control (distilled water only)

$5 \%$ extract $(15 \mathrm{ml}$ extract $+95 \mathrm{ml}$ distilled water $)$

$10 \%$ extract $(10 \mathrm{ml}$ extract $+90 \mathrm{ml}$ distilled water $)$

$15 \%$ extract $(15 \mathrm{ml}$ extract $+85 \mathrm{ml}$ distilled water)

$20 \%$ extract $(20 \mathrm{ml}$ extract $+20 \mathrm{ml}$ distilled water)

The cabofuran solutions were prepared by dissolving the required quantities in distilled water as shown below:

$\begin{array}{lll}100 \mathrm{~g} / \mathrm{ml} \text { or } 0.1 \mathrm{mg} / \mathrm{ml} & = & 0.01 \mathrm{~g} \mathrm{in} 100 \mathrm{ml} \\ 1 \mathrm{mg} / \mathrm{ml} & = & 0.1 \mathrm{gin} 100 \mathrm{ml} \\ 10 \mathrm{mg} / \mathrm{ml} & = & 1 \mathrm{gin} 100 \mathrm{ml} \\ 100 \mathrm{mg} / \mathrm{ml} & = & 0.1 \mathrm{~g} \mathrm{in} 100 \mathrm{ml}\end{array}$

\section{Effects of plant extracts on egg hatch and juvenile survival}

Aliquots of three (3) ml each of the different concentrations of each plant extract $(5,10,15$ and 20\%) as well as cabofuran solutions (100, 1,000, 10,000 and 100,000 ppm) and distilled water (controls) were dispensed into transparent glass blocks containing either fifty (50) freshly hatched root-knot juveniles or fifty (50) freshly extracted root 
knot nematode eggs. Each treatment was replicated five times. The glass blocks were arranged randomly on a work bench in the laboratory. Egg hatch counts were made at one (1), three (3), five (5) and then (10) days while a count of juvenile survival was made at one (1), three (3), six (6), twenty four (24) hours and daily for the next 5 days under a stereomicroscope using a tally counter. The experiment was a $6 \times 5$ factorial fitted into a randomized complete block design.

\section{Data analysis}

Data generated from the studies were subjected to Analysis of Variance (ANOVA) using SPSS statistical package, and the means were partitioned using the New Duncan's Multiple range test at $5 \%$ level of significance (Duncan, 1995).

\section{RESULTS}

Consideration of the main effects of the tested plant materials on egg hatch of Meloidogyne incognita revealed that in the first day, there was no significant difference among the different treatments (Table 1). Between Day 3 and Day 10, less than $20 \%$ egg hatch was observed in the various treatments. Prevention of nematode eggs hatch was significantly $(\mathrm{P} \leq 0.05)$ highest in Jatropha curcas extract. There were significant $(\mathrm{P} \leq 0.05)$ differences in egg hatch due to concentration of materials used as the extent of inhibition of egg hatch increased with increased concentration. Egg hatch was significantly highest in the untreated control.

Table 2 showed the treatment combination effects of plant materials and their levels on number of eggs hatched on Days 1, 3, 5 and 10. On Day 1, no egg hatch was observed in all the treatments except in 5\% Crotalaria retusa. It was observed that Jatropha curcas at all concentrations completely inhibited egg hath throughout the period of experiment. A similar egg hatch inhibition was observed at 15 and $20 \%$ Cleome viscosa and Jatropha gossypifolia and at 100,000 ppm carbofuran treatments throughout the period of experiment. Significantly, $(\mathrm{P} \leq 0.05)$ more eggs hatched in the untreated control than in all the treatments while the higher concentrations of the various materials were significantly $(\mathrm{P} \leq 0.05)$ more effective than their lower concentrations.

It was observed that there was a significant difference $(\mathrm{P} \leq 0.05)$ in mean nematode juvenile mortality due to the different treatment materials and the levels of application used (Table 3). Between six (6) and forty eight (48) hours of exposure to treatments, carbofuran was the most effective in causing juvenile death, followed by the Jatropha curcas and Jatropha gossyppifolia treatments. At 72 hours of exposure of the juveniles to the treatment, there was no significant difference between carbofuran and the two Jatropha extracts. It was also observed that the higher concentrations of all treatments were significantly $(\mathrm{P} \leq 0.05)$ more effective than the lower concentrations in causing 
juvenile death. All the treatments caused significantly $(\mathrm{P} \leq 0.05)$ more juvenile deaths than what was observed in the control.

Table 4 showed the effects of the combinations of materials and levels of application on the mortality of the juveniles. By the sixth hour, all the juveniles in the $10,000 \mathrm{ppm}$ and $100,000 \mathrm{ppm}$ carbofuran treatments had died. In the higher concentrations $(10 \%, 15 \%$ and $20 \%)$ of all the crude water extract treatments, more than $50 \%$ of the juveniles died by twenty-four (24) hours of exposure to treatments, while at 48 and 72 hours of exposure between $75 \%$ and $100 \%$ juvenile mortality was recorded. The efficacy of the treatment increased with increased concentrations and number of hours of exposure of the juveniles to the treatments.

\section{DISCUSSION}

The result of the in-vitro studies of plant extracts on egg hatch and juvenile mortality of the root knot nematode, Meloidogyne incognita showed the nematostatic and nematotoxic effects of the tested plant extracts. Observations showed that by 24 hours and 48 hours more than $50 \%$ and $75 \%$ of the juveniles respectively had died in most of the treatments. The observed inhibition of egg hatch and mortality of second stage juveniles of the root-knot nematode is of significant importance in reducing the nematode population build-up and the amount of available inoculum in the soil. The rapid population buildup of Meloidogyne incognita is due to its ability to lay several (600 or more) eggs (Caveness, 1967; Adesiyan et al, 1990), which later hatch to the second stage juvenile that infects the host plants (Nwauzor and Fawole, 1992).

The second stage juveniles had been reported to penetrate host plant roots within the first 48 hours of coming in contact with host (Taylor and Sasser, 1978, Nwauzor and Fawole, 1992). The fact that more than $50 \%$ and $75 \%$ of the juveniles had died in most of the treatments by twenty four (24) hours and fourty-eight (48) hours respectively, of exposure indicated a significant population reduction of the in effective juveniles at the critical period.

Sellami and Muofarrah (1994) reported that aqueous extracts of some plants leaves and roots inhibited egg hatch and caused larval mortality of Meloidogyne incognita. The extracts were from the leaves of Ricinus communis, Datura stramonum, Crotolaria saharae, Melia azederach and Calendula officinalis as well as from the leaves and roots of Tagetes minuta, T. erecta and T. Patula. The percentage inhibition of juvenile hatching varied from $21.11 \%$ for $C$. officinalis to $55.67 \%$ for $R$. communis extract. There was $95 \%$ larval mortality within 48 hours of exposure. The present study agrees with these observations.

Observations made in this study in respect of increased juvenile mortality over 
time also agreed with the works of Alam et al., (1980). They reported that extracts of Plumeria rubra (leaf and bark) and Ipomea fistulosa (leaf) were found more toxic to juveniles than Nerium indicum (leaf and fruit). Standard concentrations of all extracts caused $100 \%$ mortality within 12 hours, whereas half dilution gave $84-88 \%, 93-100 \%$ and $100 \%$ mortality after 12,24 and 48 hours respectively. Juvenile mortality increased with increase in concentrations and exposure over time. Hoseeb and Butool (1996) reported the nematicidal properties of some plants in the family Solanaceae. They determined the effects of standard extracts of roots and shoots of seven species of this plant family on the larva hatching and nematode mortality of Meloidogyne incognita in laboratory experiments. In general, the highest concentrations of water extracts of all test plants caused $100 \%$ mortality of nematode. Larva hatching and nematode mortality were strongly influenced by the concentrations of extracts, plant species and duration of exposure.

The chief advantage of the result from the findings of this experiment lies in the fact that if eggs cannot hatch, there will be no second stage juveniles in the soil to cause infection. The use of extracts from the test plants in this study, particularly Jatropha curcas, J. gossypifolia and Cleome viscose, at concentrations not less than 15-20\% holds promise as a cheaper and safer alternative to carbofuran for the control of root knot nematodes. 
Table 1: Effects of Materials (Test plants and Carbofuran) and Levels of Application on the Egg hatch of Meloidogyne incognita invitro at $25+2^{0} \mathrm{C}$

\begin{tabular}{l|c|c|c|c}
\hline \multirow{2}{*}{\multicolumn{1}{c|}{ Materials }} & \multicolumn{3}{c}{$\begin{array}{c}\text { Mean number of eggs that hatched } \\
\text { out of a total of 50 eggs. }\end{array}$} \\
\cline { 2 - 5 } Cleome viscosa & Day 1 & Day 3 & Day 5 & Day 10 \\
\hline Hyptis suaveolens & 0.00 & $0.60^{\mathrm{a}}$ & $8.67^{\mathrm{a}}$ & $9.33^{\mathrm{b}}$ \\
Crotalaria retusa & 0.00 & $2.33^{\mathrm{b}}$ & $11.00^{\mathrm{c}}$ & $12.87^{\mathrm{c}}$ \\
Jatropha curcas & 0.05 & $1.07^{\mathrm{a}}$ & $10.80^{\mathrm{c}}$ & $11.33^{\mathrm{bc}}$ \\
Jatropha gossypiifolia & 0.00 & $0.20^{\mathrm{a}}$ & $0.80^{\mathrm{a}}$ & $1.00^{\mathrm{a}}$ \\
Carbofuran & 0.00 & $0.20^{\mathrm{a}}$ & $9.80^{\mathrm{bc}}$ & $10.07^{\mathrm{b}}$ \\
S.E. & 0.00 & $0.67^{\mathrm{a}}$ & $10.53^{\mathrm{c}}$ & $10.80^{\mathrm{b}}$ \\
LEVELS & 0.12 & 0.37 & 0.67 & 0.32 \\
0\% extra/Oppm carbofuran (control) & N.S & & & \\
5\% extracts/100ppm Carboduran & 0.00 & $1.00^{\mathrm{ab}}$ & $29.28^{\mathrm{d}}$ & $33.67^{\mathrm{d}}$ \\
10\% extracts/1000ppm carbofuran & 0.04 & $1.39^{\mathrm{b}}$ & $10.50^{\mathrm{c}}$ & $12.12^{\mathrm{c}}$ \\
15\% extracts/10,000ppm Carbofuran & 0.00 & $1.39^{\mathrm{b}}$ & $3.56^{\mathrm{b}}$ & $5.94^{\mathrm{b}}$ \\
20\% extracts/100,000ppm Carbofuran & 0.00 & $0.39^{\mathrm{a}}$ & $0.50^{\mathrm{a}}$ & $1.00^{\mathrm{a}}$ \\
S.E. & 0.00 & $0.56^{\mathrm{a}}$ & $0.83^{\mathrm{a}}$ & $0.86^{\mathrm{a}}$ \\
& 0.11 & 0.30 & 0.61 & 0.30 \\
\hline
\end{tabular}

Means with the same letter(s) in separate sections of the same column are not significantly different at $\mathrm{P} \leq 0.05$ according to Duncan's Multiple Range Test.

NS $=$ No significant difference 
Table 2: Effect of Treatment Combination of Plant Materials at their Levels of Application on Egg hatch of Meloidogyne incognita invitro at $25+2^{0} \mathrm{C}$ invitro

\begin{tabular}{|c|c|c|c|c|}
\hline \multirow[t]{2}{*}{ Materials } & \multicolumn{4}{|c|}{$\begin{array}{l}\text { Mean number of eggs that hatched } \\
\text { out of a total of } 50 \text { eggs. }\end{array}$} \\
\hline & Day 1 & Day 3 & Day 5 & Day 10 \\
\hline \multicolumn{5}{|l|}{ Cleome viscose } \\
\hline $0 \%$ & $0.00^{\mathrm{a}}$ & $1.00^{\mathrm{ab}}$ & $34.33^{\mathrm{g}}$ & $40.38^{d}$ \\
\hline $5 \%$ & $0.00^{\mathrm{a}}$ & $1.67^{\mathrm{ab}}$ & $9.99^{\text {cde }}$ & $15.63^{b c}$ \\
\hline $10 \%$ & $0.00^{\mathrm{a}}$ & $0.33^{\mathrm{ab}}$ & $0.33^{\mathrm{a}}$ & $0.33^{\mathrm{a}}$ \\
\hline $15 \%$ & $0.05^{\mathrm{a}}$ & $0.00^{\mathrm{a}}$ & $0.00^{\mathrm{a}}$ & $0.00^{\mathrm{a}}$ \\
\hline $20 \%$ & $0.00^{\mathrm{a}}$ & $0.00^{\mathrm{a}}$ & $0.00^{\mathrm{a}}$ & $0.00^{\mathrm{a}}$ \\
\hline \multicolumn{5}{|l|}{ Hyptis suaveolens } \\
\hline $0 \%$ & $0.00^{\mathrm{a}}$ & $1.00^{\mathrm{a}}$ & $34.67^{\mathrm{g}}$ & $40.00^{\mathrm{d}}$ \\
\hline $5 \%$ & $0.00^{\mathrm{a}}$ & $2.00^{\mathrm{a}}$ & $13.33^{\mathrm{a}}$ & $18.00^{\mathrm{c}}$ \\
\hline $10 \%$ & $0.00^{\mathrm{a}}$ & $6.33^{c}$ & $7.00^{b c}$ & $12.00^{\mathrm{b}}$ \\
\hline $15 \%$ & $0.00^{\mathrm{a}}$ & $2.33^{\mathrm{ab}}$ & $3.00^{\mathrm{ab}}$ & $3.00^{\mathrm{a}}$ \\
\hline $20 \%$ & $0.00^{\mathrm{a}}$ & $0.00^{\mathrm{a}}$ & $0.00^{\mathrm{a}}$ & $0.00^{\mathrm{a}}$ \\
\hline \multicolumn{5}{|l|}{ Crotalaria retusa } \\
\hline $0 \%$ & $0.00^{\mathrm{a}}$ & $1.00^{\mathrm{ab}}$ & $34.33^{\mathrm{g}}$ & $41.33^{d}$ \\
\hline $5 \%$ & $2.67^{\mathrm{b}}$ & $3.00^{\mathrm{b}}$ & $19.67^{\text {cdef }}$ & $25.33^{\mathrm{cd}}$ \\
\hline $10 \%$ & $0.00^{\mathrm{a}}$ & $1.00^{\mathrm{ab}}$ & $1.00^{\mathrm{a}}$ & $1.00^{\mathrm{a}}$ \\
\hline $15 \%$ & $0.00^{\mathrm{a}}$ & $0.00^{\mathrm{a}}$ & $0.00^{\mathrm{a}}$ & $0.00^{\mathrm{a}}$ \\
\hline $20 \%$ & $0.00^{\mathrm{a}}$ & $0.33^{\mathrm{ab}}$ & $0.40^{\mathrm{a}}$ & $0.40^{\mathrm{a}}$ \\
\hline \multicolumn{5}{|l|}{ Jatropha curcas } \\
\hline $0 \%$ & $0.00^{\mathrm{a}}$ & $1.00^{\mathrm{ab}}$ & $34.33^{\mathrm{g}}$ & $41.00^{d}$ \\
\hline $5 \%$ & $0.00^{\mathrm{a}}$ & $0.00^{\mathrm{a}}$ & $0.00^{\mathrm{a}}$ & $0.00^{\mathrm{a}}$ \\
\hline $10 \%$ & $0.00^{\mathrm{a}}$ & $0.00^{\mathrm{a}}$ & $0.00^{\mathrm{a}}$ & $0.00^{\mathrm{a}}$ \\
\hline $15 \%$ & $0.00^{\mathrm{a}}$ & $0.00^{\mathrm{a}}$ & $0.00^{\mathrm{a}}$ & $0.00^{\mathrm{a}}$ \\
\hline $20 \%$ & $0.00^{\mathrm{a}}$ & $0.00^{\mathrm{a}}$ & $0.00^{\mathrm{a}}$ & $0.00^{\mathrm{a}}$ \\
\hline \multicolumn{5}{|l|}{ Jatropha gossypiifolia } \\
\hline $0 \%$ & $0.00^{\mathrm{a}}$ & $1.00^{\mathrm{a}}$ & $33.33^{\mathrm{g}}$ & $40.33^{d}$ \\
\hline $5 \%$ & $0.00^{\mathrm{a}}$ & $0.00^{\mathrm{a}}$ & $10.00^{b}$ & $10.00^{b}$ \\
\hline $10 \%$ & $0.00^{\mathrm{a}}$ & $0.00^{\mathrm{a}}$ & $5.67^{b c}$ & $5.67^{b c}$ \\
\hline $15 \%$ & $0.00^{\mathrm{a}}$ & $0.00^{\mathrm{a}}$ & $0.00^{\mathrm{a}}$ & $0.00^{\mathrm{a}}$ \\
\hline $20 \%$ & $0.00^{\mathrm{a}}$ & $0.00^{\mathrm{a}}$ & $0.00^{\mathrm{a}}$ & $0.00^{\mathrm{a}}$ \\
\hline \multicolumn{5}{|l|}{ Carbofuran } \\
\hline Oppm & $0.00^{\mathrm{a}}$ & $1.00^{\mathrm{ab}}$ & $35.00^{\mathrm{g}}$ & $40.00^{\mathrm{d}}$ \\
\hline 100ppmm & $0.00^{\mathrm{a}}$ & $0.67^{\mathrm{ab}}$ & $11.00^{\mathrm{e}}$ & $11.00^{\mathrm{e}}$ \\
\hline $1,000 \mathrm{ppm}$ & $0.00^{\mathrm{a}}$ & $1.67^{\mathrm{ab}}$ & $8.67^{\text {cde }}$ & $8.67^{\mathrm{b}}$ \\
\hline $10,000 \mathrm{ppm}$ & $0.00^{\mathrm{a}}$ & $0.00^{\mathrm{a}}$ & $3.00^{\mathrm{ab}}$ & $3.00^{\mathrm{a}}$ \\
\hline $100,000 \mathrm{ppm}$ & $0.00^{\mathrm{a}}$ & $0.00^{\mathrm{a}}$ & $0.00^{\mathrm{a}}$ & $0.00^{\mathrm{a}}$ \\
\hline S.E. & 0.27 & .83 & 1.48 & 0.73 \\
\hline
\end{tabular}

Means with the same letter(s) in separate sections of the same column are not significantly different at $\mathrm{P} \leq 0.05$ according to Duncan's Multiple Range Test. NS = No significant difference 
Table 4: $\quad$ Effects of Treatment Combination of Plant Materials and Levels of Application on Juvenile Mortality of Meloidogyne incognita invitro at 25 $\mathbf{2}^{0} \mathrm{C}$

\begin{tabular}{|c|c|c|c|c|c|}
\hline \multirow[b]{2}{*}{ Materials } & \multicolumn{5}{|c|}{ Length of Exposure (hours) } \\
\hline & $\mathbf{1}$ & 6 & 24 & 48 & 72 \\
\hline \multicolumn{6}{|l|}{ Cleome viscose } \\
\hline $0 \%$ & $0.00^{\mathrm{c}}$ & $0.00^{\mathrm{h}}$ & $0.00^{\mathrm{k}}$ & $1.00^{\mathrm{h}}$ & $1.67^{\mathrm{g}}$ \\
\hline $5 \%$ & $0.00^{\mathrm{c}}$ & $0.00^{\mathrm{h}}$ & $3.33^{\mathrm{k}}$ & $9.00^{\mathrm{g}}$ & $12.33^{\mathrm{f}}$ \\
\hline $10 \%$ & $0.00^{\mathrm{c}}$ & $3.67^{\mathrm{g}}$ & $26.33^{h}$ & $39.33^{\mathrm{cd}}$ & $50.00^{\mathrm{a}}$ \\
\hline $15 \%$ & $0.00^{\mathrm{c}}$ & $4.00^{\mathrm{gh}}$ & $38.67^{\mathrm{f}}$ & $48.53^{\mathrm{a}}$ & $50.00^{\mathrm{a}}$ \\
\hline $20 \%$ & $0.00^{\mathrm{c}}$ & $28.33^{b}$ & $44.33^{b c}$ & $50.33^{\mathrm{a}}$ & $50.00^{\mathrm{a}}$ \\
\hline \multicolumn{6}{|l|}{ Hyptis suaveolens } \\
\hline $0 \%$ & $0.00^{\mathrm{c}}$ & $0.00^{\mathrm{h}}$ & $0.00^{\mathrm{k}}$ & $0.00^{\mathrm{h}}$ & $0.67^{\mathrm{g}}$ \\
\hline $5 \%$ & $0.00^{\mathrm{c}}$ & $0.00^{\mathrm{h}}$ & $11.33^{\mathrm{j}}$ & $19.67^{f}$ & $29.33^{\mathrm{e}}$ \\
\hline $10 \%$ & $0.00^{\mathrm{c}}$ & $0.00^{\mathrm{h}}$ & $17.67^{\mathrm{i}}$ & $27.33^{\mathrm{e}}$ & $36.33^{\mathrm{d}}$ \\
\hline $15 \%$ & $0.00^{\mathrm{c}}$ & $0.00^{h}$ & $29.33^{\mathrm{gh}}$ & $38.33^{\mathrm{cd}}$ & $47.33^{\mathrm{ab}}$ \\
\hline $20 \%$ & $0.00^{\mathrm{c}}$ & $0.00^{\mathrm{h}}$ & $44.67^{\mathrm{bc}}$ & $50.00^{\mathrm{a}}$ & $50.00^{\mathrm{a}}$ \\
\hline \multicolumn{6}{|l|}{ Crotalaria retusa } \\
\hline $0 \%$ & $0.00^{c}$ & $0.00^{h}$ & $0.00^{\mathrm{k}}$ & $0.00^{\mathrm{h}}$ & $0.67^{g}$ \\
\hline $5 \%$ & $0.00^{\mathrm{c}}$ & $0.00^{\mathrm{h}}$ & $11.67^{\mathrm{j}}$ & $17.33^{\mathrm{f}}$ & $29.33^{\mathrm{e}}$ \\
\hline $10 \%$ & $0.00^{c}$ & $1.33^{\mathrm{gh}}$ & $17.33^{\mathrm{i}}$ & $27.00^{\mathrm{e}}$ & $36.33^{\mathrm{d}}$ \\
\hline $15 \%$ & $0.00^{c}$ & $0.00^{\mathrm{h}}$ & $31.00^{\mathrm{gh}}$ & $42.00^{\mathrm{bc}}$ & $47.33^{\mathrm{ab}}$ \\
\hline $20 \%$ & $0.00^{c}$ & $2.33^{\mathrm{g}}$ & $43.67^{\text {cde }}$ & $50.00^{\mathrm{a}}$ & $50.00^{\mathrm{a}}$ \\
\hline \multicolumn{6}{|l|}{ Jatropha curcas } \\
\hline $0 \%$ & $0.00^{c}$ & $0.00^{\mathrm{h}}$ & $0.00^{\mathrm{k}}$. & $0.00^{\mathrm{h}}$ & $0.67^{\mathrm{g}}$ \\
\hline $5 \%$ & $0.00^{c}$ & $8.67^{f}$ & $19.67^{\mathrm{i}}$ & $37.33^{\mathrm{d}}$ & $39.33^{\mathrm{e}}$ \\
\hline $10 \%$ & $0.00^{\mathrm{c}}$ & $19.67^{d}$ & $32.67^{\mathrm{g}}$ & $45.67^{\mathrm{ab}}$ & $46.00^{\mathrm{b}}$ \\
\hline $15 \%$ & $0.00^{\mathrm{c}}$ & $19.67^{\mathrm{d}}$ & $39.67^{\text {ef }}$ & $50.00^{\mathrm{a}}$ & $50.00^{\mathrm{a}}$ \\
\hline $20 \%$ & $0.00^{c}$ & $25.00^{\mathrm{c}}$ & $46.67^{\mathrm{abc}}$ & $50.00^{\mathrm{a}}$ & $50.00^{\mathrm{a}}$ \\
\hline \multicolumn{6}{|l|}{ Jatropha gossypiifolia } \\
\hline $0 \%$ & $0.00^{\mathrm{c}}$ & $0.00^{\mathrm{h}}$ & $0.00^{\mathrm{k}}$ & $0.67^{\mathrm{g}}$ & $0.67^{\mathrm{g}}$ \\
\hline $5 \%$ & $0.33^{c}$ & $10.00^{f}$ & $20.67^{\mathrm{i}}$ & $42.33^{c}$ & $42.33^{c}$ \\
\hline $10 \%$ & $5.67^{\mathrm{b}}$ & $14.00^{\mathrm{c}}$ & $27.67^{\mathrm{h}}$ & $49.00^{\mathrm{a}}$ & $50.00^{\mathrm{a}}$ \\
\hline $15 \%$ & $8.67^{\mathrm{a}}$ & $1867^{\mathrm{d}}$ & $40.00 \mathrm{~d}^{\mathrm{ef}}$ & $50.00^{\mathrm{a}}$ & $50.00^{\mathrm{a}}$ \\
\hline $20 \%$ & $0.00^{\mathrm{c}}$ & $21.67^{\mathrm{d}}$ & $49.00^{\mathrm{ab}}$ & $50.00^{\mathrm{a}}$ & $50.00^{\mathrm{a}}$ \\
\hline \multicolumn{6}{|l|}{ Carbofuran } \\
\hline Oppm & $0.00^{\mathrm{c}}$ & $0.00^{\mathrm{h}}$ & $0.00^{\mathrm{k}}$ & $0.00^{\mathrm{h}}$ & $0.67^{\mathrm{g}}$ \\
\hline 100рpmm & $0.00^{\mathrm{c}}$ & $18.67^{\mathrm{d}}$ & $29.67^{\mathrm{g}}$ & $50.00^{\mathrm{a}}$ & $50.00^{\mathrm{a}}$ \\
\hline 1,00ppm & $0.00^{\mathrm{c}}$ & $27.67^{b c}$ & $50.00^{\mathrm{a}}$ & $50.00^{\mathrm{a}}$ & $50.00^{\mathrm{a}}$ \\
\hline $10,000 \mathrm{ppm}$ & $0.00^{\mathrm{c}}$ & $50.00^{\mathrm{a}}$ & $50.00^{\mathrm{a}}$ & $50.00^{\mathrm{a}}$ & $50.00^{\mathrm{a}}$ \\
\hline $100,000 \mathrm{ppm}$ & $0.00^{\mathrm{c}}$ & $50.00^{\mathrm{a}}$ & $50.00^{\mathrm{a}}$ & 50.00 & $50.00^{\mathrm{a}}$ \\
\hline S.E. & 0.3 & 0.97 & 1.51 & 1.4 & 0.86 \\
\hline
\end{tabular}

Means with the same alphabet(s) in the same column are not significantly different at $\mathrm{P} \leq 0.05$ according to Duncan's Multiple Range Test. NS = No significant difference 


\section{REFERENCES}

Abolusoro, S.A. (2005). Nematicidal activities of some selected botanicals on a rootknot nematode, Meloidogyne incognita affecting tomato, Lycopersicon escidentum L. (mill) Ph.D thesis. University of Ilorin, Nigeria, AP2006

Adesiyan, S. O., Caveness, F.E., Adeniyi, M.A. and Fawole, B. (1990). Nematode Pests of Tropical Crops, PTF Low Price Edition, Heinemann Educational Books (Nigeria) Plc, pp. 9-17\&114.

Ajayi, V.A., Akem, C.N. and Adesiyan, S.O. (1993). Comparison of nematicidal potentials of $V$. amygdalina leaf extract and carbofura on the growth and yield of root knot nematode infested soyabean. Afro Asian J, Nemat. 3(2): 119-127.

Alam, M.M. Ahmad and A.M. Khan (1980). The Effect of Organic Amendments on the growth and chemical Composition of Tomato, Eggplant, chili and their susceptibility to Attack by Meloidogyne incognita". Plant and Soil. 57:231-236

Caveness, F.E. (1967). End of Tour progress Reports on the Nematology Project. USAID, Lagos, Nigeria, pp. 135.

Hoseeb, A and Butool, B. (1996). Evaluation of Nematicidal Properties of Some Members of the Family Solanaceae. Bioresource Technology 57 (1): 95-97.

Nwauzor, E.C. and B. Fawole (1992). The Development and Life Cycle of Meloidogyne incognita (race 2) in Dioscorea rotunda var. Okwocha. Proc, $1^{\text {st }}$ Regional symposium on the Biology and Control of Nematode Pests on Food Crops in Africa. Univ. of Ibadan Press. Nigeria $26^{\text {th }}-29^{\text {th }}$ July 1992, : 17-133. 
Oyedunmade, E.E.A. (2004). Laboratory and field toxicities of the Africa marigold, Tagetes erecta to root knot nematodes. The Plant Scientist 4(4): 115-121.

Saxena, J. and Mathela, C.S. (1996). Antifungal Activity of New Compounds from Napeta leucophylla and Napeta clarka. Applied and Environmental Microbiology 62(2): 702-704.

Sellami, S. and Mouffarah, A. (1994). Effect of Aqueous Plant Extracts on Juvenile Hatching and Larval Mortality against Meloidogyne incognita. Medelingen Faculteit-Land Bouwkundige-EN TOEYE Paste lologi shewntensch APPEN Univesitei Gent 59(26) 813-816.

Taylor, L and Sasser J.N (1978). Biology, Identification and Control of root-knot nematodes (Meloidogyne spp). North Carolina University Graphic Press. 111. 